\title{
Specific root respiration of three plant species as influenced by storage time and conditions
}

\author{
Zana A. Lak • Hans Sandén • Mathias Mayer • Boris \\ Rewald (D)
}

Received: 27 March 2020 / Accepted: 22 June 2020 /Published online: 30 June 2020

(C) The Author(s) 2020

\begin{abstract}
Aims Specific root respiration $\left(\mathrm{RR}_{\mathrm{S}}\right)$ is a key root trait, determining i.e. nutrient foraging and uptake efficiencies. However, a considerable uncertainty exists regarding the effects of storage time and conditions on $R_{S}$ measurements.

Methods Fine root $\mathrm{CO}_{2}$ efflux rates of three plant types (tree seedling Carpinus betulus, legume Pisum sativum, grass Lolium perenne) were measured as depending on storage time (30-1440 min post-rinsing) and conditions (i.e. attached to plant, warm and cold water storage, and storage under dry conditions).

Results Short-term storage conditions (30 $\mathrm{min}$ ) had a significant effect on measured $R R_{S}$ rates, in specific, $R_{S}$ rates of all three species were significantly lower under dry storage. Irrespective of plant species or temperature, storage of excised roots in water did not affect $\mathrm{RR}_{\mathrm{S}}$ for $300 \mathrm{~min}, \mathrm{RR}_{\mathrm{S}}$ measurements remained stable for 1 day if roots were stored cold.
\end{abstract}

Responsible Editor: Amandine Erktan.

Electronic supplementary material The online version of this article (https://doi.org/10.1007/s11104-020-04619-9) contains supplementary material, which is available to authorized users.

Z. A. Lak · H. Sandén · M. Mayer · B. Rewald $(\bowtie)$ Institute of Forest Ecology, Department of Forest and Soil Sciences, University of Natural Resources and Life Sciences Vienna, Peter-Jordan-Strasse 82, 1190 Vienna, Austria e-mail: boris.rewald@boku.ac.at

\section{Z. A. Lak}

Agriculture College, Forestry Department, Salahaddin University, Kurdistan region, Erbil, Iraq
Conclusions Our results have important implications on measurement routines of $\mathrm{RR}_{\mathrm{S}}-\mathrm{a}$ generally understudied root trait. Henceforth it seems reasonable to collect roots in the field and transport them, hydrated but even uncooled, to the laboratory for subsequent measurements for at least 300 min post-rinsing.

Keywords Excised plant roots - Root respiration - Root traits $\cdot$ Sample storage $\cdot$ Specific root respiration

\section{Introduction}

Root respiration (RR) is a major component of the terrestrial carbon cycle, contributing $10-90 \%$ to total soil respiration (Bond-Lamberty et al. 2004; Hanson et al. 2000). In certain cases, RR can account for up to $75 \%$ of the assimilated carbon allocated to roots (Majdi et al. 2007), and extensive carbon costs of RR have been directly related to growth above ground (e.g. Rewald et al. 2016). Specific root respiration $\left(R R_{S}\right)$ is defined as the amount of $\mathrm{CO}_{2}$ released or $\mathrm{O}_{2}$ absorbed per unit root during a given time; $\mathrm{RR}_{\mathrm{S}}$ originates from three physiological processes: ion mobilization and uptake, growth and defence, and cell maintenance (Van der Werf et al. 1994). Although respiration of root-associated microbes such as mycorrhizal fungi can contribute to measured $\mathrm{RR}_{\mathrm{S}}$ rates (Bulgarelli et al. 2012; Nielsen et al. 1998), the specific carbon or $\mathrm{O}_{2}$ costs per unit root indicate carbon- or $\mathrm{O}_{2}$-use efficiencies, respectively. Consequently, $R_{\mathrm{S}}$ is a key root trait determining i.e. nutrient 
foraging/uptake efficiencies (George et al. 2003; Lynch 2015).

Specific root respiration of various plant species, different root entities and ontogenetic stages have been measured (Freschet et al. 2020; Lambers et al. 2002). Specific root respiration varies largely among plants and are generally considered greater in fast-growing species (Poorter et al. 1990; Rewald et al. 2014). Within root systems, $\mathrm{RR}_{\mathrm{S}}$ of young, distal roots are often greater than those of coarser, older roots (which are e.g. lignified, containing less nitrogen, and having a greater stele fraction). Specific root respiration is subjected to considerable environmental influences, including temperature, water availability, ion concentrations in the soil solution, or $\mathrm{O}_{2}$ availability. For example, with an increase in temperature, $\mathrm{RR}_{\mathrm{S}}$ increases and it is generally modelled using a temperature sensitivity coefficient $\left(\mathrm{Q}_{10}\right)$ near 2; however, large differences between species and root types regarding $\mathrm{Q}_{10}$ values and the rate and degree of temperature acclimation have been reported (Atkinson et al. 2007; Freschet et al. 2020). Specific root respiration is often decreasing as soil moisture deficits are increasing; similar, $\mathrm{O}_{2}$ deficiency or high $\mathrm{CO}_{2}$ concentrations may inhibit $\mathrm{RR}_{\mathrm{S}}$ (Freschet et al. 2020). Regarding the composition of the soil solution, acquisition and assimilation of ammonium is often less carbon costly than that of nitrate (Bloom et al. 1992; Rewald et al. 2016) and concentrations of other nutrients and heavy metals alter $R R_{S}$ rates depending on concentrations (e.g. Otgonsuren et al. 2016). Potentially related to the amount of carbon assimilates available, $R_{\mathrm{S}}$ was found to vary or not over the course of a day (e.g. Trolldenier and von Rheinbaben 1981; Widén and Majdi 2001).

Direct measurement of $\mathrm{CO}_{2} / \mathrm{O}_{2}$ fluxes of roots are frequently performed in closed chamber systems on excised samples - limiting confounding effects by heterotrophic soil respiration, and allowing for measurements on clearly defined root entities (see Freschet et al. (2020) for a recent review on root respiration measurements in the context of standardized root trait measurements). Sampled roots are either rinsed (with tap water) or brushed free of substrate (Makita et al. 2012). Despite the growing popularity of $\mathrm{RR}_{\mathrm{S}}$ measurements, possibly fostered by the broad availability of infra-red gasanalyser (IRGA) systems, it is currently uncertain how long and under which conditions (different) roots can be stored without affecting $\mathrm{RR}_{\mathrm{S}}$. This information is key to harmonize $\mathrm{RR}_{\mathrm{S}}$ measurement protocols, and thus to improve the comparability of measurements; this is of particular importance due to the increasing emphasis on trait-function relationships in plant ecology (Westoby and Wright 2006) and the ongoing assembly of large plant trait databases (e.g. FRED, the largest fine-root trait database to date; Iversen et al. 2017).

Thus, the aims of this study were to clarify how premeasurement conditions, in specific the time span until measurements after root rinsing/excision, and the storage conditions (incl. media and temperature), influence the measurements of specific root respiration rates, and if this differs between three contrasting plant species.

\section{Material and methods}

Plant species and experiment set-up

The plants for the experiment were grown in a ventilated polytunnel greenhouse, under slightly increased temperature and near ambient lighting conditions, at BOKU Tulln, Austria $\left(48^{\circ} 19^{\prime} 05.0^{\prime \prime} \mathrm{N}, 16^{\circ} 03^{\prime} 58.2^{\prime \prime} \mathrm{E}\right)$. End of March 2017, 1.5-year-old, bare-rooted Carpinus betulus L. seedlings (European hornbeam; Murauer Forstpflanzen GmbH, Ort im Innkreis, Austria), and Pisum sativum L. cv. 'Retrija' (Pea; Institute of Agricultural Resources and Economics, Priekul,i Research Centre, Latvia) and Lolium perenne L. cv. 'Jubilee' (Perennial ryegrass; terrasan $\mathrm{GmbH}$, Rain am Lech, Germany) seeds were obtained. Carpinus betulus is a broadleaved, deciduous, small to medium-sized tree with a wide natural distribution range across CentralSoutheast Europe and commonly cultivated as an ornamental tree across Europe. Pisum sativum is an annual, cool-season legume grown in many parts of the world as crop. Lolium perenne is a fast-growing, perennial grass species that requires a large amount of nitrogen $(\mathrm{N})$; it is a most important pasture and forage grass, and frequently used in gardens, parks and sport grounds. The plants were planted / seeded during early April 2017 in 71 pots (ca. $35 \mathrm{~cm}$ in height) filled with washed quartz sand (particle size distribution $0.7-1.2 \mathrm{~mm}$ ); the upper $10 \mathrm{~cm}$ of substrate per pot were amended with $10 \mathrm{~g}$ of slowrelease fertilizer (Osmocote Pro 3-4 M, Everris, The Netherlands). Sand is allowing for non-destructive, relatively fast root system harvest. One tree individual, 3 peas and ca. 30 ryegrass seeds were planted / placed per pot; germination rates were high $(>95 \%)$. Thirty pots were established per species. An automated irrigation 
system was used to supply all pots with ample and uniform amounts of water; irrigation was adjusted to climate conditions and free drainage of pots was provided. Pots were kept free of weeds and no pests were observed. Plants were grown under the described conditions from early April to the end of June 2017.

Root system rinsing, and pre-measurement storage conditions

At the beginning of July 2017, all pots were transported to a growth room at BOKU Wien and acclimated to the 'indoor' conditions for at least 7 days $\left(20^{\circ} \mathrm{C}, 60 \%\right.$ relative humidity, $12 \mathrm{~h}$ light (fluorescence light bulbs, 400-500 $\mu \mathrm{mol} \mathrm{m} \mathrm{m}^{-2} \mathrm{~s}^{-1}$ )) before measurements started; plants were irrigated and weeded as needed. About $>3 \mathrm{~h}$ after light was turned on (to avoid potential diurnal effects), pots were randomly selected and brought to the laboratory. There the root systems were carefully cleaned from quartz sand and rinsed under tap water (2$3 \mathrm{~min}$ ); the time the root systems were rinsed is considered time ' 0 '. Four different storage conditions (treatments) were subsequently established: Attached (A), Warm (W), Cold (C), and Dry (D; Table 1). The establish storage conditions aimed to provide most contrasting storage conditions in terms of excision, storage media and temperature rather than emulating specific storage conditions being used by individual research groups. Roots of treatment A remained connected to the shoot(s) after rinsing and were placed in an aerated water bath at room temperature $\left(22-23^{\circ} \mathrm{C}\right)$; the leaves were illuminated $\left(400-500 \mu \mathrm{mol} \mathrm{m} \mathrm{m}^{-2} \mathrm{~s}^{-1}\right)$ to allow photosynthesis to continue. After $\sim 30,60,120,180$, and $300 \mathrm{~min}$ in the water bath, subsamples of roots close to the shoot (in P. sativum and L. perenne) or of fine roots (diameter $\leq 2 \mathrm{~mm}$; $C$. betulus) were excised and subjected to immediate respiration measurements. In treatment A, each excised root subsample was measured only once after excision; time point 1440 min was not measured in treatment A. Accordingly, measurement cycles are denoted as A1 to A5. Roots from treatments $\mathrm{W}$ and $\mathrm{C}$ were excised immediately (i.e. 1-2 $\mathrm{min}$ ) after rinsing and stored in tap water-filled plastic tubes at $28^{\circ} \mathrm{C}$ and $4{ }^{\circ} \mathrm{C}$ until respiration measurements, respectively. $\mathrm{W}$ and $\mathrm{C}$ root samples were subjected to repeated ('R') measurements ( 30, 60, 180, 300 and $1440 \mathrm{~min}$ after excision); after each measurement cycle, roots were placed back into water-filled plastic tubes for inbetween measurement storage. In addition, some roots of treatment $\mathrm{C}$ were stored for 60 (C2) and $180 \mathrm{~min}(\mathrm{C} 4)$ without intermediate measurements to determine the effects of repeated warming $(C R)$ on $R_{S}$ of cold stored roots. Roots from treatment $\mathrm{D}$ were also excised directly after rinsing but were stored on petri dishes under room conditions $\left(\sim 22-23{ }^{\circ} \mathrm{C}, \sim 40-60 \%\right.$ relative humidity) until and in-between respiration measurements $(\sim 30$, $60,180,300$ and $1440 \mathrm{~min}$ after excision). Accordingly, the first measurement cycles are denoted as W1, C1, and $\mathrm{D} 1$, while the following, repeated cycles are denoted as WRx, CRx, and DRx (R for 'repeated' measurements on a sample used at a previous time point; $x=2-6$ ). See Table 1 for details.

\section{Root respiration}

Prior to respiration measurements $\sim 2 \mathrm{~g}$ (fresh weight) roots of treatments $\mathrm{A}, \mathrm{C}$, and $\mathrm{W}$ were placed in a beaker filled with $20^{\circ} \mathrm{C}$ tap water for $\sim 2-3$ min (to facilitate temperature acclimation); fine roots of $\mathrm{D}$ were placed in a climate cabinet at $20^{\circ} \mathrm{C}$. Root fresh weights of $\sim 2 \mathrm{~g}$ per sample correspond to average dry weights of $450 \pm$ $6 \mathrm{mg}$ (C. betulus), $135 \pm 2 \mathrm{mg}$ (P. sativum), and $246 \pm$ $4 \mathrm{mg}$ (L. perenne) as determined at the end of the experiment. Subsequently, A-, W- and C-stored roots were gently blotted surface dry. All roots were then placed in acclimated $\left(20{ }^{\circ} \mathrm{C}\right), 55 \mathrm{ml}$ plastic tubes ('chambers') itself placed in a climate cabinet $(20 \pm$ $0.1{ }^{\circ} \mathrm{C}$ ); the $\mathrm{CO}_{2}$ efflux from roots (i.e. root respiration) was determined in air by means of the closed-chamber technique, connecting the chambers to an infra-red gas analyser (IRGA, EGM-5; PP-Systems International, Inc. Amesbury, MA, USA; 65\% pump speed). After $60 \mathrm{~s}$ of equilibration (air mixing within chamber), changes in $\mathrm{CO}_{2}$ concentration (ppm; $\Delta \mathrm{CO}_{2}$ ) within the chamber was recorded every $30 \mathrm{~s}$ for $2-3 \mathrm{~min}$ until $\Delta \mathrm{CO}_{2}>50 \mathrm{ppm}$. In general, measurements started at the earliest $30 \mathrm{~min}$ after IRGA start-up allowing for stable IRGA temperatures; 'zero setting' was performed regularly. Air $\mathrm{CO}_{2}$ concentrations in chambers at the start of recordings were in the range of 450-600 ppm. Root respiration rate was calculated from a cubic regression fitted to the relationship between measurement time and $\mathrm{CO}_{2}$ concentration (Kutzbach et al. 2007). Specific (fine) root respiration rates per biomass $\left(\mathrm{RR}_{\mathrm{S}} ; \mathrm{nmol} \mathrm{CO}_{2}\right.$ $\mathrm{g}^{-1} \mathrm{~s}^{-1}$ ) were calculated, taking headspace, air pressure, temperature, and root dry mass into account (Lamouroux 2008). According to the specific storage conditions / time points, root samples were carefully 
Table 1 Respiration measurements on Carpinus betulus, Pisum sativum, and Lolium perenne roots per storage conditions (Treatments), defined by storage media (tap water or air) and temperature $\left(4^{\circ} \mathrm{C}, 22-23{ }^{\circ} \mathrm{C}^{*}\right.$, or $\left.28{ }^{\circ} \mathrm{C}\right)$, repeated or single ('once') measurements per root sample, and time of excision / measurements relative to the time of root system rinsing (time ' 0 '). Time intervals measured are marked by the specific sample number $(n=$ 25-30); n.a. not available

\begin{tabular}{|c|c|c|c|c|c|c|c|c|c|c|c|}
\hline \multirow[t]{2}{*}{$\begin{array}{l}\text { Treatment } \\
\text { (Abbreviation) }\end{array}$} & \multicolumn{2}{|l|}{ Storage } & \multirow{2}{*}{$\begin{array}{l}\text { Measurem. } \\
\text { per } \\
\text { sample }\end{array}$} & \multirow[t]{2}{*}{$\begin{array}{l}\text { Rinsing } \\
(\min )\end{array}$} & \multirow[t]{2}{*}{ Time of excision (min) } & \multicolumn{6}{|c|}{$\begin{array}{l}\text { Realized measurement intervals, after } \\
\text { rinsing the root system ( } \pm 5 \mathrm{~min})\end{array}$} \\
\hline & Media & $\begin{array}{l}\text { Temp. } \\
\left({ }^{\circ} \mathrm{C}\right)\end{array}$ & & & & 30 & 60 & 120 & 180 & 300 & 1440 \\
\hline Attached (A) & Water $^{\S}$ & $22-23 *$ & Once & 0 & $\begin{array}{l}\sim 5 \pm 2 \text { (before each } \\
\text { measurement) }\end{array}$ & A1 & A2 & $\mathbf{A 3}$ & A4 & A5 & n.a. \\
\hline Warm $(W)$ & Water & 28 & Once & 0 & $<2$ after rinsing & W1 & n.a. & n.a. & n.a. & n.a. & n.a. \\
\hline $\begin{array}{l}\text { Warm Repeated } \\
\quad \text { (WR) }\end{array}$ & Water & 28 & Repeated & 0 & $<2$ & & WR2 & WR3 & WR4 & WR5 & WR6 \\
\hline Cold $(C)$ & Water & 4 & Once & 0 & $<2$ & C1 & $\mathrm{C} 2$ & n.a. & $\mathrm{C} 4$ & n.a. & n.a. \\
\hline $\begin{array}{l}\text { Cold Repeated } \\
\quad(C R)\end{array}$ & Water & 4 & Repeated & 0 & $<2$ & & CR2 & CR3 & CR4 & CR5 & CR6 \\
\hline $\operatorname{Dry}(D)$ & Air* & $22-23 *$ & Once & 0 & $<2$ & D1 & n.a. & n.a. & n.a. & n.a. & n.a. \\
\hline $\begin{array}{l}\text { Dry Repeated } \\
\quad(D R)\end{array}$ & Air* & $22-23 *$ & Repeated & 0 & $<2$ & & DR2 & DR3 & DR4 & DR5 & DR6 \\
\hline
\end{tabular}

$\S$ aerated; *i.e. room conditions

retrieved from the $55 \mathrm{ml}$ plastic tubes with tweezers and either returned to water-filled storage beakers for repeated measurements or placed in water for root imaging. Subsequently to respiration measurements, root samples were imaged with a flatbed scanner, and images were analysed for morphological root traits (see Supplementary Material for details). Root samples were dried $\left(65{ }^{\circ} \mathrm{C}\right)$ and dry mass was determined to an accuracy of $\pm 0.1 \mathrm{mg}$. Dried fine roots were ground to powder, five times pooling five samples per species, and total carbon and nitrogen concentrations were determined (see Supplementary Material for details). Means of morphological and chemical root traits per species were related by linear regression analysis to mean specific root respiration rates (samples A1); relating morphological and chemical root traits to other mean $\mathrm{RR}_{\mathrm{S}}$ (samples WR1, CR1, DR1) did not result in improved regressions (data not shown). Means of CR2,4 and C2,4 samples were compared to determine potential effects of interim warming on $\mathrm{RR}_{\mathrm{S}}$ after longer cold storage.

\section{Statistical analysis}

Statistical analyses were carried out in IBM SPSS 24.0 and Microsoft Excel 2013. The effect of species, time and treatment were analysed by one-way General Linear Model (GLM) followed by Tukey's post-hoc test. Data was log-transformed to reach the requirements of the
GLM. A one sample T-test was used to determine if respiration rates differed from 0 . Statistical relationships were considered significant at $p<0.05$. All data is displayed as mean \pm standard error (SE).

\section{Results}

Species specific root respiration rates after $30 \mathrm{~min}$ of storage under different conditions

Among the three species and across the four different storage conditions (A1, W1, C1 and D1; Table 1), $P$. sativum possessed the greatest $\mathrm{RR}_{\mathrm{S}}$ rates, ranging from $4.0 \mathrm{nmol} \mathrm{CO}_{2} \mathrm{~g}^{-1} \mathrm{~s}^{-1}$ after 30 min under D ('Dry') storage conditions to $31.1 \mathrm{nmol} \mathrm{CO}_{2} \mathrm{~g}^{-1} \mathrm{~s}^{-1}$ after 30 min under W ('Warm') storage conditions (Table 2). Similarly, $\mathrm{RR}_{\mathrm{S}}$ rates of $C$. betulus and L. perenne varied between 2.7 and $2.3 \mathrm{nmol} \mathrm{CO}_{2}$ $\mathrm{g}^{-1} \mathrm{~s}^{-1}$ after D-storage conditions, to 12.7 .5 and 20.7 nmol $\mathrm{CO}_{2} \mathrm{~g}^{-1} \mathrm{~s}^{-1}$ after W-storage conditions, respectively.

Storage conditions had a significant effect on the measured $R R_{S}$ rates, i.e. $R R_{S}$ rates were in all three species significantly lower after D-storage when compared to other storage conditions (Table 2). For $P$. sativum and L. perenne roots, storage under $\mathrm{W}$ conditions led to significantly greater $R_{S}$ rates when 
Table 2 Specific root respiration rates $\left(\mathrm{RR}_{\mathrm{S}} ; \mathrm{nmol} \mathrm{CO}_{2} \mathrm{~g}^{-1} \mathrm{~s}^{-1}\right.$, $20^{\circ} \mathrm{C}$ ) of the species Carpinus betulus, Pisum sativum and Lolium perenne $30 \pm 5 \mathrm{~min}$ after root system rinsing. Root storage conditions: Attached (A1), Cold (C1), Warm (W1) and Dry (D1), see Table 1 for details. Measurements were conducted $5 \pm 2$ min after excision (A), or $30 \pm 5$ min after root excision (C, W, and D). Significant differences between species are indicated by different capital letters, significant differences between storage conditions by small letters (mean \pm SE; Tukey test, $\mathrm{p}<0.05$; $\mathrm{n}=25-30$ )

\begin{tabular}{lllll}
\hline Species & \multicolumn{4}{l}{ Specific root respiration $\left(\mathrm{RR}_{\mathrm{S}} ; \mathrm{nmol} \mathrm{CO}_{2} \mathrm{~g}^{-1} \mathrm{~s}^{-1}\right)$ per storage condition } \\
\cline { 2 - 5 } & Attached (A1) & Warm $(\mathrm{W} 1)$ & Cold (C1) & Dry (D1) \\
\hline C. betulus & $9.8 \pm 1.0 \mathrm{Ba}$ & $12.7 \pm 1.0 \mathrm{Ca}$ & $11.0 \pm 1.3 \mathrm{Ba}$ & $2.7 \pm 0.2 \mathrm{ABb}$ \\
$P$. sativum & $16.2 \pm 1.0 \mathrm{Ab}$ & $31.1 \pm 2.2 \mathrm{Aa}$ & $20.7 \pm 3.6 \mathrm{Ab}$ & $4.0 \pm 0.6 \mathrm{Ac}$ \\
L. perenne & $14.3 \pm 1.0 \mathrm{Aab}$ & $20.7 \pm 3.4 \mathrm{Ba}$ & $10.3 \pm 1.0 \mathrm{Bb}$ & $2.3 \pm 0.3 \mathrm{Bc}$ \\
\hline
\end{tabular}

compared to $\mathrm{C}$ - (both species) and A-storage (P. sativum only) conditions; no effect of the 3 different 'water' storage conditions on $\mathrm{RR}_{\mathrm{S}}$ was found for C. betulus. The ranking of species according to absolute $\mathrm{RR}_{\mathrm{S}}$ rates and the significance of differences between species varied according to storage conditions. For example, using roots which were 'attached' (A) to the plant until shortly before the measurements resulted in non-significant differences between the $\mathrm{RR}_{\mathrm{S}}$ of P. sativum (16.2 $\mathrm{nmol} \mathrm{CO} \mathrm{g}^{-1} \mathrm{~s}^{-1}$ ) and L. perenne (14.3 nmol $\mathrm{CO}_{2} \mathrm{~g}^{-1} \mathrm{~s}^{-1}$ ), with $C$. betulus featuring significant lower $\mathrm{RR}_{\mathrm{S}}\left(9.8 \mathrm{nmol} \mathrm{CO} \mathrm{g}^{-1} \mathrm{~s}^{-1}\right)$. In contrast, cold (C) storage conditions resulted in nonsignificant differences between $\mathrm{RR}_{\mathrm{S}}$ rates of $C$. betulus $\left(11.0 \mathrm{nmol} \mathrm{CO}_{2} \mathrm{~g}^{-1} \mathrm{~s}^{-1}\right)$ and L. perenne $\left(10.3 \mathrm{nmol} \mathrm{CO}_{2}\right.$ $\left.\mathrm{g}^{-1} \mathrm{~s}^{-1}\right)$ but significant greater $\mathrm{RR}_{\mathrm{S}}$ rates of $P$. sativum (20.7 $\mathrm{nmol} \mathrm{CO}_{2} \mathrm{~g}^{-1} \mathrm{~s}^{-1}$ ) compared to both other species. A significant difference between the $R R_{S}$ rates of all three species was found under $\mathrm{W}$-storage conditions only (Table 2).

Specific root respiration rates after extended storage under different conditions

The $R R_{S}$ rates of the three species reacted differently to extended storage times and this was additionally modulated by storage conditions (Fig. 1). Compared to the respective measurements at $30 \mathrm{~min}(9.8-12.7 \mathrm{nmol} \mathrm{CO} 2$ $\left.\mathrm{g}^{-1} \mathrm{~s}^{-1}\right)$, the treatments A, WR and CR did not result in a significant decline of $C$. betulus' $\mathrm{RR}_{\mathrm{S}}$ within $300 \mathrm{~min}$ (8.2-11.6 nmol $\mathrm{CO}_{2} \mathrm{~g}^{-1} \mathrm{~s}^{-1}$, respectively; Fig. 1A). Interestingly, the $\mathrm{RR}_{\mathrm{S}}$ of $C$. betulus roots were significantly increased after $1440 \mathrm{~min}$ of WR-storage conditions (17.2 nmol CO $2 \mathrm{~g}^{-1} \mathrm{~s}^{-1}$ ). In contrast, $\mathrm{RR}_{\mathrm{S}}$ of $C$. betulus roots stored under DR conditions were significantly reduced from $180 \mathrm{~min}$ (DR; $1.7 \mathrm{nmol} \mathrm{CO}_{2} \mathrm{~g}^{-1} \mathrm{~s}^{-1}$ ) onwards. Particularly starting from $300 \mathrm{~min}$, significant differences in $\mathrm{RR}_{\mathrm{S}}$ could be noticed for $C$. betulus roots between most storage treatments, WR-stored roots having the significant greatest $\mathrm{RR}_{\mathrm{S}}$ values (Supplementary Table S1). Similar to C. betulus, the $\mathrm{RR}_{\mathrm{S}}$ rates of $P$. sativum measured after $30 \mathrm{~min}$ remained significantly unaltered under A, WR and CR treatments until $300 \mathrm{~min}$, and even at $1440 \mathrm{~min}$ (CR and WR) (Fig. 1B). Roots stored at DR treatment possessed a significant reduction in $\mathrm{RR}_{\mathrm{S}}$ after $300 \mathrm{~min}$. In L. perenne both $\mathrm{WR}$ and $\mathrm{CR}$ conditions, although possessing largely different $R_{\mathrm{S}}$ towards each other, resulted in significantly unaltered $\mathrm{RR}_{\mathrm{S}}$ rates until 1440 min (Fig. 1C). Under 'attached' conditions, the $\mathrm{RR}_{\mathrm{S}}$ of $L$. perenne was significantly reduced by $\sim 30 \%$ after $300 \mathrm{~min}\left(10.3 \mathrm{nmol} \mathrm{CO} \mathrm{g}^{-1} \mathrm{~s}^{-1}\right)$ of storage after rinsing/excision compare to $\mathrm{RR}_{\mathrm{S}}$ measured at $30 \mathrm{~min}\left(14.7 \mathrm{nmol} \mathrm{CO} \mathrm{g}^{-1} \mathrm{~s}^{-1}\right)$. The very low $\mathrm{RR}_{\mathrm{S}}$ rates of $L$. perenne under dry storage conditions remained comparably stable until $180 \mathrm{~min}$; after that, they declined significantly. In both $P$. sativum and L. perenne, significant differences between storage treatment WR, and both $\mathrm{A}$ and $\mathrm{CR}$ storage conditions occurred from the first measurement at $30 \mathrm{~min}$, with warm storage continuously resulting in greatest $R R_{S}$ rates (Supplementary Table $S 1$ ).

The $R_{R}$ rates of cold-stored roots did not show significant differences when comparing repeated measurements CR2 and CR4 to single measurements C2 and C4, respectively (Supplementary Fig. S1).

Root morphological and chemical traits and their relation to $R R_{S}$

The three species differed significantly with regard to all morphological and most chemical root traits assessed (Table 3). The specific root length (SRL) as well as the specific root area (SRA) were significantly smallest in 

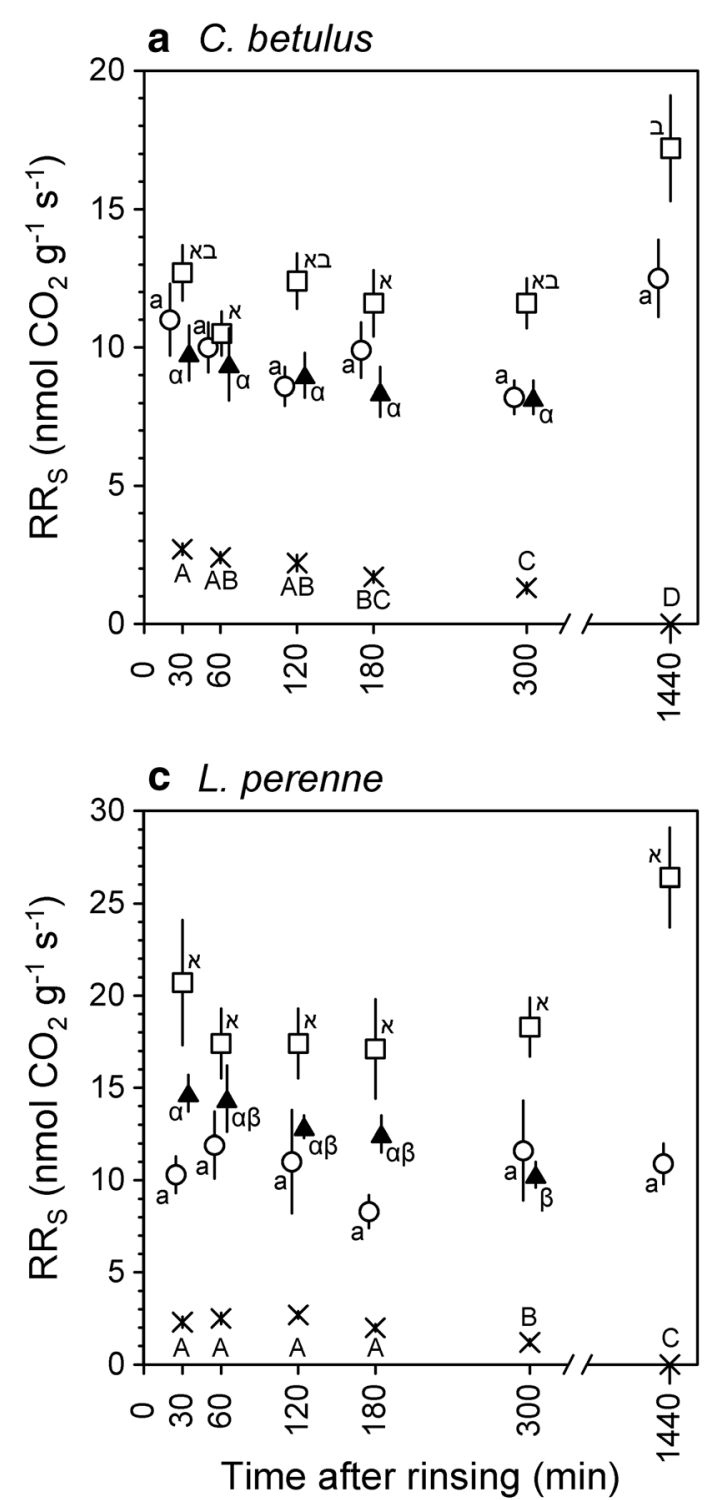

Fig. 1 Specific root respiration $\left(\mathrm{RR}_{\mathrm{S}} ; 20{ }^{\circ} \mathrm{C}\right)$ of A Carpinus betulus, B Pisum sativum, and $\mathbf{C}$ Lolium perenne (fine) roots stored under the conditions (treatments) Attached (A1-5; Triangle), Warm (WR1-6; Square), Cold (CR1-6, Circle), or Dry (DR1-6, Cross) for 30, 60, 120, 180, 300 (and 1440) min after root system rinsing; see Table 1 for details. Please note the

C. betulus fine roots $(\mathrm{d}<2 \mathrm{~mm})$. L. perenne was featuring the significant greatest SRL $\left(8024 \mathrm{~cm} \mathrm{~g}^{-1}\right)$ and SRA $\left(2110 \mathrm{~cm}^{2} \mathrm{~g}^{-1}\right)$ values of the three species. In accordance, tissue density (TD) was significant greatest in C. betulus fine roots $\left(0.099 \mathrm{~g} \mathrm{~cm}^{-3}\right)$ with about 4-fold lower values in $P$. sativum $\left(0.028 \mathrm{~g} \mathrm{~cm}^{-3}\right)$ and L. perenne $\left(0.024 \mathrm{~g} \mathrm{~cm}^{-3}\right)$. Nitrogen concentrations were significantly greatest in P. sativum roots $(2.6 \%)$,

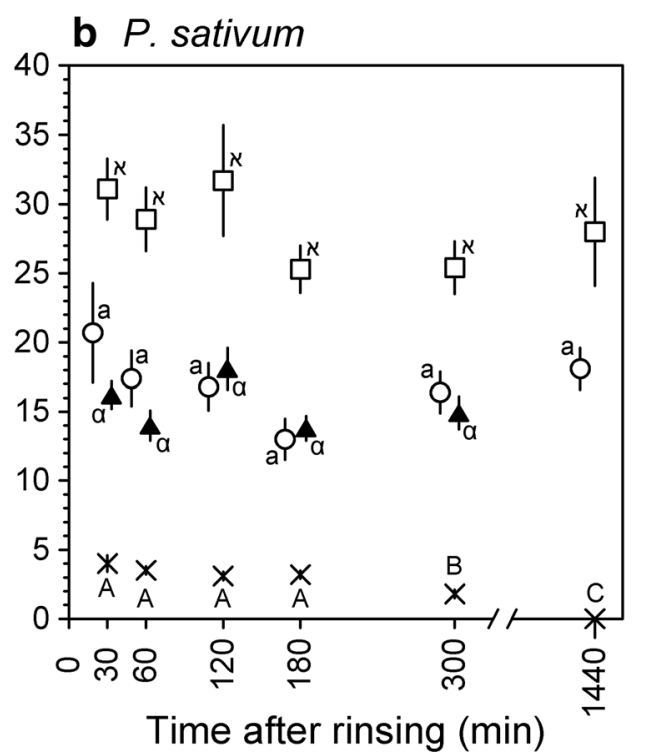

1 A1-5 (Attached)
으 WR1-6 (Warm)
† CR1-6 (Cold)
* DR1-6 (Dry)

different $Y$-axis scales. Significant differences between time of measurements within treatments are denoted by different Greek (A), Hebrew (WR), small Latin (CR), and capital Latin (DR) letters (mean $\pm \mathrm{SE}$; Tukey test on log-transformed data, $p<0.05$; $\mathrm{n}=25-30$ ). See Supplementary Table $\mathrm{S} 1$ for statistics comparing $\mathrm{RR}_{\mathrm{S}}$ between treatments per time point

followed by $C$. betulus fine roots (1.6\%) and the significant least concentrations were found in L. perenne roots (1.2\%). Carbon concentrations were more similar, but with significant differences between $C$. betulus fine roots $(49.4 \%)$ and $L$. perenne roots $(46.2 \%)$. Carbon to nitrogen ratio was clearly lowest in $P$. sativum roots, with nearly twice as high carbon to nitrogen ratios in both other species (Table 3). We found no significant 
Table 3 (Fine) root morphological and chemical traits of the species Carpinus betulus, Pisum sativum and Lolium perenne. Morphology traits are specific root length (SRL), specific root area (SRA), and tissue density (TD); root chemical traits are total nitrogen $(\mathrm{N})$ and carbon $(\mathrm{C})$ concentrations and the $\mathrm{C}: \mathrm{N}$ ratio. Significant between species are indicated by different capital letters (mean \pm SE; Tukey test, $\mathrm{p}<0.05 ; \mathrm{n}(\mathrm{SRL}, \mathrm{SRA}, \mathrm{TD})=25-30$, $\mathrm{n}(\mathrm{N}, \mathrm{C}, \mathrm{C}: \mathrm{N})=5)$

\begin{tabular}{|c|c|c|c|c|c|c|}
\hline Species & $\operatorname{SRL}\left(\mathrm{cm} \mathrm{g}^{-1}\right)$ & SRA $\left(\mathrm{cm}^{2} \mathrm{~g}^{-1}\right)$ & $\mathrm{TD}\left(\mathrm{mg} \mathrm{cm}^{-3}\right)$ & $\mathrm{N}$ Conc. $\left(\mathrm{mg} \mathrm{g}^{-1}\right)$ & C Conc. ( $\mathrm{mg} \mathrm{g}^{-1}$ ) & $\mathrm{C}: \mathrm{N}$ ratio \\
\hline C. betulus & $2616 \pm 49 \mathrm{~A}$ & $601 \pm 8 \mathrm{~A}$ & $99 \pm 0.20 \mathrm{C}$ & $16 \pm 0.3 \mathrm{~B}$ & $494 \pm 4 \mathrm{~B}$ & $31 \pm 0.4 \mathrm{~B}$ \\
\hline P. sativum & $7412 \pm 146 \mathrm{~B}$ & $1851 \pm 29 \mathrm{~B}$ & $28 \pm 0.06 \mathrm{~B}$ & $26 \pm 0.3 \mathrm{C}$ & $477 \pm 6 \mathrm{AB}$ & $18 \pm 0.3 \mathrm{~A}$ \\
\hline L. perenne & $8024 \pm 214 \mathrm{C}$ & $2110 \pm 40 \mathrm{C}$ & $24 \pm 0.07 \mathrm{~A}$ & $12 \pm 0.4 \mathrm{~A}$ & $462 \pm 9 \mathrm{~A}$ & $38 \pm 1.2 \mathrm{C}$ \\
\hline
\end{tabular}

linear relation between mean $R_{S}$ rates and mean root traits of species, neither for morphological nor for chemical root traits (Supplementary Fig. S2).

\section{Discussion}

Specific root respiration of plant species and their dependency on short-term storage conditions

The measured specific root respiration $\left(R R_{S}\right)$ rates are in the range of previously reported values. For example, the studies listed in the FRED fine-root database (https://roots.ornl.gov; 09.03.2020) reported $\mathrm{RR}_{\mathrm{S}}$ values of 1.7-11.2 $\mathrm{nmol} \mathrm{CO}_{2} \mathrm{~g}^{-1} \mathrm{~s}^{-1}$ for fine roots of deciduous, broadleaved tree species, 4.9-32.9 nmol $\mathrm{CO}_{2} \mathrm{~g}^{-1} \mathrm{~s}^{-1}$ for herbs, and 2.4-22.2 $\mathrm{nmol} \mathrm{CO}_{2} \mathrm{~g}^{-1} \mathrm{~s}^{-1}$ for $\mathrm{C} 3$ graminoids (Iversen et al. 2018). Rewald et al. (2014) reported $R_{\mathrm{S}}$ rates of $\sim 16 \mathrm{nmol} \mathrm{O}_{2} \mathrm{~g}^{-1} \mathrm{~s}^{-1}$ (20 ${ }^{\circ} \mathrm{C}$ ) for $C$. betulus fine roots; although the respiratory quotient remains unknown, this is considerable more than the $\mathrm{RR}_{\mathrm{S}}$ of $C$. betulus fine roots reported in this study ( 10-13 nmol $\mathrm{CO}_{2} \mathrm{~g}^{-1} \mathrm{~s}^{-1}$; Table 2, Suppl. Table S1). For P. sativum, Ryle et al. (1983) reported $\mathrm{RR}_{\mathrm{S}}$ of $6.7 \pm 0.3 \mathrm{mg} \mathrm{CO} \mathrm{g}^{-1} \mathrm{~h}^{-1} ; \sim 42 \mathrm{nmol} \mathrm{CO}$ $\mathrm{g}^{-1} \mathrm{~s}^{-1}$ ), and de Visser and Lambers (1983) reported $\mathrm{RR}_{\mathrm{S}}$ of 5-11 $\mathrm{mg} \mathrm{O}_{2} \mathrm{~g}^{-1} \mathrm{~h}^{-1}\left(\sim 43-95 \mathrm{nmol} \mathrm{O} \mathrm{g}^{-1} \mathrm{~s}^{-1}\right)$ largely depending on cultivar, $\mathrm{N}$ source and root age; both measurement ranges being much greater compared to the values of this study $\left(\sim 16-31 \mathrm{nmol} \mathrm{CO}_{2} \mathrm{~g}^{-1} \mathrm{~s}^{-1}\right)$. This discrepancy could be potentially related to the fact that we did not observe a pronounced Rhizobia establishment, i.e. nodules were infrequent and formed only very small protuberances (by visual observation, not quantified), on the sand-grown, fertilized and noninoculated P. sativum roots; nodules are known to feature great respiration rates (Lambers et al. 2002 and references within). The $\mathrm{RR}_{\mathrm{S}}$ of $L$. perenne was previously determined as $\sim 14 \mathrm{nmol} \mathrm{CO} \mathrm{gg}^{-1} \mathrm{~s}^{-1}$, and thus within the range of values determined in this study (Table 2), and deemed high compared to the $R_{S}$ of 12 other perennial grass species (Picon-Cochard et al. 2012 ). In our study, the greater $\mathrm{RR}_{\mathrm{S}}$ of the legume $P$. sativum could be partially related to the greater nitrogen concentration in its roots (Table 3); previous studies have reported strong correlations between root nitrogen concentrations and $\mathrm{RR}_{\mathrm{S}}$ (Atkinson et al. 2007; Ceccon et al. 2016; Tang et al. 2019). However, in this study we could not determine a significant linear correlation between $R_{S}$ of the three plant species and their respective root nitrogen concentration (Supplementary Fig. S2)-likely because of the great $\mathrm{RR}_{\mathrm{S}}$ of the grass $L$. perenne beside its relatively low root $\mathrm{N}$ concentration (Table 3). Furthermore, while it can be well assumed that the sum of different traits above- and belowground (e.g. availability of photosynthetic assimilates, or tissue density) is affecting plant species' or even genotypes' $\mathrm{RR}_{\mathrm{S}}$ (Lai et al. 2015; Picon-Cochard et al. 2012; Rewald et al. 2014), we did not find any significant correlation between mean $R_{S}$ rates (at $30 \mathrm{~min}$, and any storage treatment) and the six morphological or chemical traits tested (displayed for treatment A1 in Supplementary Fig. S2). However, our and previous studies evidenced that the three plant species generally differ in their $R_{S}$ (Table 2).

Species-specific $\mathrm{RR}_{\mathrm{S}}$ rates were, however, already significantly influenced by short-term differences in storage conditions (i.e. $30 \mathrm{~min}$ since root system rinsing). In specific, $R_{R}$ rates were significantly lower after dry storage (D), i.e. the placement of surface wet roots on petri dishes exposed to common room conditions for $30 \mathrm{~min}$. This can be explained by reduced physiological activity of tissues from dehydration (Baena-González and Sheen 2008); soil moisture deficits have previously found exerting a substantial negative influence on $\mathrm{RR}_{\mathrm{S}}$ (Bryla et al. 
2001; Jarvi and Burton 2013). In accordance, Leprince et al. (2000) previously reported gradually decreasing $\mathrm{CO}_{2}$ efflux rates from $P$. sativum radicles during progressing dehydration.

For P. sativum, warm storage (W) led to a significantly higher $R R_{S}$ rate when compared to $A$ and $C$ treatments (Table 2). This might be related to an incomplete temperature adjustment of $\mathrm{W}$-stored roots (storage at $28^{\circ} \mathrm{C}$ ) to a flux measurement temperature of $20^{\circ} \mathrm{C}$, as $\mathrm{RR}_{\mathrm{S}}$ rates are generally positively related to increasing temperature (Atkin et al. 2000). However, the oposite effect was not noticed for C-stored roots $\left(4{ }^{\circ} \mathrm{C}\right)$, although the temperature difference was much greater. Furthermore, utmost care was taken to prevent root temperatures to deviate from the flux measurement temperature of $20^{\circ} \mathrm{C}$ (see Materials and Methods). Thus, we interpret the greater $R_{S}$ in W-treated $P$. sativum rather as a 'lag' effect of the previous, short-term warm-storage. In this species, the assumed fast acclimation of root respiration to storage at $28{ }^{\circ} \mathrm{C}$, after being exposed to $20{ }^{\circ} \mathrm{C}$ for $>7$ days, might thus indicate rather rapid changes in the demand for ATP for maintenance processes rather than enzyme capacity (Atkin et al. 2000). In contrast, $\mathrm{RR}_{\mathrm{S}}$ of cold-stored roots were not significantly different from those subjected to A-storage. Thus, our results might indicate that warming leads to a rapid acclimation of root respiration in some, more active species, with no evidence for a rapid acclimation to cold conditions. Although not the focus of this work, these results are indicative of a strong non-linearity in root $\mathrm{Q}_{10}$ 's (see Atkin et al. 2000 and discussion within); this phenomenon requires further studies.

Comparing the short-term storage treatments, our study shows that 1) root storage in water is generally preferable to storage under dry conditions, 2) root storage in warm water may significantly increase $\mathrm{RR}_{\mathrm{S}}$ in metabolically very active species such as $P$. sativum, and 3 ) $\mathrm{RR}_{\mathrm{S}}$ rates from roots stored in cold water are comparable to that of recently excised roots (i.e. A treatment). However, our data also shows that the degree of species differentiation is largely influenced by storage conditions. In specific, differences in $\mathrm{RR}_{\mathrm{S}}$ among all species were only statistically significant under $\mathrm{W}$-storage; under $\mathrm{A}$ - and $\mathrm{C}$-storage conditions $\mathrm{RR}_{\mathrm{S}}$ of either $P$. sativum and $L$. perenne (under A) or C. betulus and L. perenne (under C) were statistically similar (Table 2).
Effects of extended storage and storage condition on $\mathrm{RR}_{\mathrm{S}}$ measurements

Information on which carbon pools are respired by roots (i.e. recent assimilates compared to carbon stored in the plant/organ) is not yet very comprehensive, but recent studies indicate that roots may combine recent carbon assimilates with carbon from a stored pool to fuel (fine) root respiration (see Lynch et al. 2013 and references within). The amount of stored carbon used to fuel root respiration is likely differing between species and ontogenetic stages, as well as seasonally and/or even diurnally (Bahn et al. 2006; Hansen 1977; Hopkins et al. 2013; Kuptz et al. 2011). As recent photosynthate relocation ceases after shoot clipping, and stored carbon levels in roots are assumed to decline rapidly, the time span between root sampling and $\mathrm{RR}_{\mathrm{S}}$ measurements is usually kept as short as possible (Bloom and Caldwell 1988; Freschet et al. 2020). Labelled photosynthetic carbon can be respired in roots as fast as within $0.5-$ $2 \mathrm{~h}$ after photosynthetic assimilation (Yoshida and Eguchi 1992 and references within); Kuzyakov et al. (2001) calculated a rather direct use of recently assimilated carbon for root respiration (95\% within 1 day). Accordingly, e.g. Bingham and Rees (2008) reported a $\sim 50 \%$ decline of the respiration rates of excised Trifolium roots after $24 \mathrm{~h}$. However, Leprince et al. (2000) indicated earlier that incubating isolated $P$. sativum and Cucumis sativus radicles on wet filter paper did not induce significant changes in $\mathrm{CO}_{2}$ emission rates over a period of $4 \mathrm{~h}$. Moreover, Bahn et al. (2006) reported that clipping did not significantly affect root respiration rates of temperate grass species for up to 14 days in situ-indicating that $\mathrm{RR}_{\mathrm{S}}$ was largely maintained by carbon reserves in roots or stolons. This coincided with findings of Bazot et al. (2005), which showed on mature L. perenne plants that root soluble carbon concentrations even increased for several days after defoliation (but see Smith and Stitt 2007 for Arabidopsis). Although we are not aware of long-term measurements of tree $\mathrm{RR}_{\mathrm{S}}$ after shoot/stem clipping / root excision, it has been similarly estimated that the amount of carbon stored in tree roots may buffer effects of reduced assimilate supply for several days to weeks (Högberg et al. 2001; Pregitzer et al. 2000). In accordance, e.g. Keith (1998) showed that phosphorous uptake by excised Eucalyptus nitens fine roots was significantly reduced 5 days after sampling only. In the light of these findings, our study confirms that appropriate storage conditions 
generally enable to measure $\mathrm{RR}_{\mathrm{S}}$ after extended storage times, resulting in $R_{S}$ rates comparable to those measured $30 \mathrm{~min}$ after excision (Fig. 1). The different effects of storage conditions, as outlined above, are largely maintained over time (Supplementary Table S1). Storage in water did generally not result in significant changes in $\mathrm{RR}_{\mathrm{S}}$ among plant all three species until 300 min (beside A-storage in in L. perenne, see discussion below), and partially until $1440 \mathrm{~min}$ (i.e. 1 day) after root rinsing. This was particular surprising for $\mathrm{W}-$ storage conditions as we had assumed that the greater metabolic rates maintained in warm water would result in a (faster) depletion of easily available carbon reserves and thus a faster reduction in $R_{S}$ rates. Instead, we even noticed a significant increase of $\mathrm{RR}_{\mathrm{S}}$ in $\mathrm{W}$-stored C. betulus roots and similar tendencies in L. perenne roots at $1440 \mathrm{~min}$ (Fig. 1). It seem reasonable to speculate that this might (partially) relate to an increased heterotrophic respiration by entophytic microbes. For example, earlier studies have shown that the senescence of plant tissue can rapidly convert microbes from being passive members of the endophytic microbial community to a saprotrophic lifestyle (Porras-Alfaro and Bayman 2011) - with potential effects on their metabolic activity. However, no significant effects of cold storage were found in any of the three species at $1440 \mathrm{~min}$ (CR6) compared to $\mathrm{C} 1$, indicating a general suitability of extended cold storage to conserve roots for later $R_{S}$ measurements. As we did not find significant differences in C vs. CR root samples (Supplementary Fig. $\mathrm{S} 1$ ), we conclude that temporal warming in-between cold-storage periods has only minor effects on $R_{S}$ measurements (at least until 180 min with 3 preceding warming periods).

Under extended dry storage, and thus continued dehydration (see discussion above), $\mathrm{RR}_{\mathrm{S}}$ continued to decline, particularly starting to be significant from 120 or 180 min compared to D1; however, the rate of decline was at a much slower rate compared to the decline during the first $30 \mathrm{~min}$ of dry storage. While Lafta and Fugate (2009) found that cell membrane damage after excessive dehydration accelerated respiration in postharvest Beta vulgaris (storage) roots, this did not apply to the (fine) root respiration measurements conducted here. Leprince et al. (2000) reported that the rates of $\mathrm{CO}_{2}$ produced by desiccation-sensitive $P$. sativum radicles during progressing dehydration were at least 2-fold higher than those in tolerant radicles. Assuming that fine roots of woody species are more tolerant to desiccation than roots of herb or grass species, our data does indicate that at $30 \mathrm{~min}$ of D-storage the relative decline in RRS (compared to A) is indeed lower in C. betulus than the two other species. However, there is not evidence for a longer 'maintenance' of $\mathrm{RR}_{\mathrm{S}}$ in $\mathrm{D}$-stored $C$. betulus fine roots compared to the other species as $\mathrm{RR}_{\mathrm{S}}$ of all three species was not significantly different from zero at 1440 min (Fig. 1) .

The study of Hansen (1977) indicated that the $\mathrm{CO}_{2}$ release from Lolium multiflorum roots in aerated Hoagland solutions was rather dependent on preceding irradiance conditions and diurnal cycles, than to extended storage in aerated nutrient solutions. Thus, we were surprised of the significant decline in $\mathrm{RR}_{\mathrm{S}}$ in 'attached' L. perenne roots $300 \mathrm{~min}$ post-rinsing. However, neither for $C$. betulus nor for P. sativum the continued cultivation in hydroponics resulted in significant differences. As previous studies have successfully grown L perenne in hydroponic systems, we can only speculate that the cultivar 'Jubilee' might hold relative high water-soluble carbohydrate concentrations (Smith et al. 2002) — which may have been leached to a greater extend in the aerated solution and thus led to a reduction in stored carbon available for respiration.

Comparing the long-term storage treatments, our study showed that 1) storage in water for $180 \mathrm{~min}$ is generally suitable for delayed determination of $R_{S}$ irrespective of plant species or storage temperature. 2) Effects of longer storage periods (>180 min) depend largely on storage conditions, while differences in $\mathrm{RR}_{\mathrm{S}}$ caused by the storage conditions remain largely stable over time. Among the tested conditions, 3) cold-storage conditions seem most suitable to achieve stable $\mathrm{RR}_{\mathrm{S}}$ measurements on excised roots - as minor differences to A-conditions occurred and values remained stable for 1 day post-excision. In general, our data suggests that the degree of species differentiation in $\mathrm{RR}_{\mathrm{S}}$, i.e. $C$. betulus $<L$. perenne $<P$. sativum, is largely maintained by storage periods up to $300 \mathrm{~min}$, although largest differences occurred under warm storage conditions (until $1440 \mathrm{~min}$ ).

\section{Conclusion and outlook}

While wound reactions after root severance have been suggested to result in greater $\mathrm{RR}_{\mathrm{S}}$ rates (Makita et al. 2012), we consider this effect minimal in our study as the severed root surface is negligible compared to the large amount of root biomass utilized. Moreover, careful 
root rinsing from the sandy substrate did not result in visible damages such as larger amounts of detached root tips. A methodological challenge in determining species' $R_{\mathrm{S}}$ remain the effects of rooting media and root excision per se on root respiration rates. For example, Cheng et al. (2005) showed that compared to a root excision method, the root respiration rate of longleaf pine measured by a field chamber method was $18 \%$ higher when using native soil as rooting medium, was similar in prairie soil, but was $42 \%$ lower in sandvermiculite medium. In addition, the presented data emphasizes that pre-measurement storage conditions of excised roots can have effects on $\mathrm{RR}_{\mathrm{S}}$ of a similar magnitude than excision per se-emphasizing the importance of using either highly standardized measurement protocols for determining plant functional traits or providing exact descriptions of pre-measurement conditions. Our findings are also providing evidence that extended storage time (i.e. beyond 180 or $300 \mathrm{~min}$ ) does not necessarily result in significantly altered $R_{S}$ rates. This has important implications on measurement routines of $\mathrm{RR}_{\mathrm{S}}$, a generally understudied root trait; henceforth it seems reasonable to collect roots in the field and transport them, even uncooled, to the laboratory for subsequent measurements (if kept moist). We speculate that this holds especially true for larger plants, which may hold sufficient carbohydrate reserves sustaining root metabolism rates for an extended time (see also discussion in Bahn et al. 2006). Future studies should compare the effects of ontogenetic stages on suitable storage times before $\mathrm{RR}_{\mathrm{S}}$ (or any other physiological) measurements, further explore the suitability to supply exogenous sugars to stabilize $\mathrm{RR}_{\mathrm{S}}$ rates (Bingham and Rees 2008) or test other relevant storage conditions (e.g. keeping moist roots (potentially wrapped in wetted paper) in closed bags, or 'storage' of roots within soil monoliths). In addition, it seems advisable to further examine the effects of excision and rinsing on $R_{S}$ compared to in situ measurements of $\mathrm{RR}_{\mathrm{S}}$ per se, particularly considering the effects of epi- and endophytic microbial activities on measured specific respiration rates.

\footnotetext{
Acknowledgements ZL was partially financially supported by a $\mathrm{PhD}$ scholarship (KRG / HCDP program) awarded by the Ministry of Higher Education and Scientific Research, Erbil, Kurdistan Region of Iraq. We thank Bradley Matthews for his advice to ZL concerning flux rate calculations. The comments of four anonymous reviewers are highly acknowledged for improving an earlier version of the manuscript.
}

Author contribution statement BR designed the study. ZL conducted the measurements with help by BR. ZL, HS, MM and $\mathrm{BR}$ analysed the data. ZL and BR provided the first draft of the manuscript; all co-authors jointly edited and revised the manuscript and approved its (re-)submission.

Funding Information Open access funding provided by University of Natural Resources and Life Sciences Vienna (BOKU).

Open Access This article is licensed under a Creative Commons Attribution 4.0 International License, which permits use, sharing, adaptation, distribution and reproduction in any medium or format, as long as you give appropriate credit to the original author(s) and the source, provide a link to the Creative Commons licence, and indicate if changes were made. The images or other third party material in this article are included in the article's Creative Commons licence, unless indicated otherwise in a credit line to the material. If material is not included in the article's Creative Commons licence and your intended use is not permitted by statutory regulation or exceeds the permitted use, you will need to obtain permission directly from the copyright holder. To view a copy of this licence, visit http://creativecommons.org/licenses/by/4.0/.

\section{References}

Atkin OK, Edwards EJ, Loveys BR (2000) Response of root respiration to changes in temperature and its relevance to global warming. New Phytol 147:141-154

Atkinson LJ, Hellicar MA, Fitter AH, Atkin OK (2007) Impact of temperature on the relationship between respiration and nitrogen concentration in roots: an analysis of scaling relationships, Q10 values and thermal acclimation ratios. New Phytol 173:110-120. https://doi.org/10.1111/j.14698137.2006.01891.x

Baena-González E, Sheen J (2008) Convergent energy and stress signaling. Trends Plant Sci 13:474-482

Bahn M, Knapp M, Garajova Z, Pfahringer N, Cernusca A (2006) Root respiration in temperate mountain grasslands differing in land use. Glob Chang Biol 12:995-1006. https://doi. org/10.1111/j.1365-2486.2006.01144.X

Bazot S, Mikola J, Nguyen C, Robin C (2005) Defoliationinduced changes in carbon allocation and root soluble carbon concentration in field-grown Lolium perenne plants: do they affect carbon availability, microbes and animal trophic groups in soil? Funct Ecol 19:886-896

Bingham I, Rees R (2008) Senescence and N release from clover roots following permanent excision of the shoot. Plant Soil 303:229-240

Bloom AJ, Caldwell RM (1988) Root excision decreases nutrient absorption and gas fluxes. Plant Physiol 87:794-796

Bloom AJ, Sukrapanna SS, Warner RL (1992) Root respiration associated with ammonium and nitrate absorption and assimilation by barley. Plant Physiol 99:1294-1301

Bond-Lamberty B, Wang C, Gower ST (2004) A global relationship between the heterotrophic and autotrophic components of soil respiration? Glob Chang Biol 10:1756-1766. https://doi.org/10.1111/j.1365-2486.2004.00816.x 
Bryla DR, Bouma TJ, Hartmond U, Eissenstat DM (2001) Influence of temperature and soil drying on respiration of individual roots in citrus: integrating greenhouse observations into a predictive model for the field. Plant Cell Environ 24:781-790

Bulgarelli D, Rott M, Schlaeppi K, van Themaat EVL, Ahmadinejad N, Assenza F, Rauf P, Huettel B, Reinhardt R, Schmelzer E (2012) Revealing structure and assembly cues for Arabidopsis root-inhabiting bacterial microbiota. Nature 488:91

Ceccon C, Tagliavini M, Schmitt AO, Eissenstat DM (2016) Untangling the effects of root age and tissue nitrogen on root respiration in Populus tremuloides at different nitrogen supply. Tree Physiol

Cheng WX, Fu SL, Susfalk RB, Mitchell RJ (2005) Measuring tree root respiration using ${ }^{13} \mathrm{C}$ natural abundance: rooting medium matters. New Phytol 167:297-307. https://doi. org/10.1111/j.1469-8137.2005.01427.x

de Visser R, Lambers H (1983) Growth and the efficiency of root respiration of Pisum sativum as dependent on the source of nitrogen. Physiol Plant 58:533-543. https://doi.org/10.1111 /j.1399-3054.1983.tb05739.x

Freschet GT, Pagès L, Iversen CM, Comas LH, Rewald B, Roumet $\mathrm{C}$, Klimešová J, Zadworny $\mathrm{M}$, Poorter $\mathrm{H}$, Postma JA, Adams TS, Bagniewska-Zadworna A, Blancaflor EB, Brunner I, Cornelissen JHC, Garnier E, Gessler A, Hobbie SE, Lambers H, Meier IC, Mommer L, Picon-Cochard C, Rose L, Ryser P, Scherer-Lorenzen M, Soudzilovskaia NA, Stokes A, Sun T, Valverde-Barrantes OJ, Weemstra M, Weigelt A, Wurzburger N, York LM, Batterman SA, Bengough AG, Gomes de Moraes M, Janeček $\breve{S}$, Salmon V, Tharayil N, McCormack ML (2020) A starting guide to root ecology: strengthening ecological concepts and standardizing root classification, sampling, processing and trait measurements. New Phytol under review

George K, Norby RJ, Hamilton JG, DeLucia EH (2003) Fine-root respiration in a loblolly pine and sweetgum forest growing in elevated $\mathrm{CO}_{2}$. New Phytol 160:511-522. https://doi. org/10.1046/j.1469-8137.2003.00911.x

Hansen GK (1977) Adaption to photosynthesis and diurnal oscillation of root respiration rates for Lolium multiflorum. Physiol Plant 39:275-279. https://doi.org/10.1111/j.13993054.1977.tb01883.x

Hanson PJ, Edwards NT, Garten CT, Andrews JA (2000) Separating root and soil microbial contributions to soil respiration: a review of methods and observations. Biogeochemistry 48:115-146

Högberg P, Nordgren A, Buchmann N, Taylor AFS, Ekblad A, Hogberg MN, Nyberg G, Ottosson-Lofvenius M, Read DJ (2001) Large-scale forest girdling shows that current photosynthesis drives soil respiration. Nature 411:789-792. https://doi.org/10.1038/35081058

Hopkins F, Gonzalez-Meler MA, Flower CE, Lynch DJ, Czimczik C, Tang J, Subke JA (2013) Ecosystem-level controls on root-rhizosphere respiration. New Phytol 199:339-351

Iversen CM, McCormack ML, Powell AS, Blackwood CB, Freschet GT, Kattge J, Roumet C, Stover DB, Soudzilovskaia NA, Valverde-Barrantes OJ, van Bodegom PM, Violle C (2017) A global fine-root ecology database to address belowground challenges in plant ecology. New Phytol 215:15-26. https://doi.org/10.1111/nph.14486
Iversen CM, Powell AS, McCormack ML, Blackwood CB, Freschet GT, Kattge J, Roumet C, Stover DB, Soudzilovskaia NA, Valverde-Barrantes OJ, van Bodegom PM, Violle C (2018) Fine-root ecology database (FRED): a global collection of root trait data with coincident site, vegetation, edaphic, and climatic data, version 2. Oak Ridge National Laboratory, TES SFA, U.S. Department of Energy, oak ridge, Tennessee, U.S.A

Jarvi MP, Burton AJ (2013) Acclimation and soil moisture constrain sugar maple root respiration in experimentally warmed soil. Tree Physiol 33:949-959. https://doi.org/10.1093 /treephys/tpt068

Keith H (1998) Calibration of the 32P bioassay for eucalypt roots in the field. Soil Biol Biochem 30:651-660

Kuptz D, Fleischmann F, Matyssek R, Grams TE (2011) Seasonal patterns of carbon allocation to respiratory pools in 60-yr-old deciduous (Fagus sylvatica) and evergreen (Picea abies) trees assessed via whole-tree stable carbon isotope labeling. New Phytol 191:160-172

Kutzbach L, Schneider J, Sachs T, Giebels M, Nykänen H, Shurpali NJ, Martikainen PJ, Alm J, Wilmking M (2007) $\mathrm{CO}_{2}$ flux determination by closed-chamber methods can be seriously biased by inappropriate application of linear regression. Biogeosciences 4:1005-1025

Kuzyakov Y, Ehrensberger H, Stahr K (2001) Carbon partitioning and below-ground translocation by Lolium perenne. Soil Biol Biochem 33:61-74

Lafta AM, Fugate KK (2009) Dehydration accelerates respiration in postharvest sugarbeet roots. Postharvest Biol Technol 54: 32-37

Lai Z, Zhang Y, Wu B, Qin S, Feng W, Liu J (2015) Impacts of morphological traits and temperature on fine root respiration during dormancy of Caragana korshinskii. Ecol Res 30:337345

Lambers H, Atkin OK, Millenaar FF (2002) Respiratory patterns in roots in relation to their functioning. In: Waisel Y, Eshel A, Kafkafi U (eds) Plant roots: the hidden half. Marcel Dekker, New York

Lamouroux C (2008) Chamber systems measurements of soil CO2 effluxes: application and methodology. Applied Physics Department. University of Granada, Granada, Spain

Leprince O, Harren FJ, Buitink J, Alberda M, Hoekstra FA (2000) Metabolic dysfunction and unabated respiration precede the loss of membrane integrity during dehydration of germinating radicles. Plant Physiol 122:597-608

Lynch JP (2015) Root phenes that reduce the metabolic costs of soil exploration: opportunities for 21 st century agriculture. Plant Cell Environ 38:1775-1784. https://doi.org/10.1111 /pce. 12451

Lynch DJ, Matamala R, Iversen CM, Norby RJ, Gonzalez-Meler MA (2013) Stored carbon partly fuels fine-root respiration but is not used for production of new fine roots. New Phytol 199:420-430. https://doi.org/10.1111/nph.12290

Majdi H, Nylund JE, Agren GI (2007) Root respiration data and minirhizotron observations conflict with root turnover estimates from sequential soil coring. Scand J For Res 22:299_ 303

Makita N, Yaku R, Ohashi M, Fukuda K, Ikeno H, Hirano Y (2012) Effects of excising and washing treatments on the root respiration rates of Japanese cedar (Cryptomeria japonica) 
seedlings. J For Res:1-5. https://doi.org/10.1007/s10310012-0355-0

Nielsen KL, Bouma TJ, Lynch JP, Eissenstat DM (1998) Effects of phosphorus availability and vesicular-arbuscular mycorrhizas on the carbon budget of common bean (Phaseolus vulgaris). New Phytol 139:647-656

Otgonsuren B, Rewald B, Godbold DL, Göransson H (2016) Ectomycorrhizal inoculation of Populus nigra modifies the response of absorptive root respiration and root surface enzyme activity to salinity stress. Flora 224:123-129. https://doi.org/10.1016/j.flora.2016.07.016

Picon-Cochard C, Pilon R, Tarroux E, Pagès L, Robertson J, Dawson L (2012) Effect of species, root branching order and season on the root traits of 13 perennial grass species. Plant Soil 353:47-57. https://doi.org/10.1007/s11104-011$1007-4$

Poorter H, Remkes C, Lambers H (1990) Carbon and nitrogen economy of 24 wild species differing in relative growth rate. Plant Physiol 94:621-627

Porras-Alfaro A, Bayman P (2011) Hidden Fungi, emergent properties: endophytes and microbiomes. Annu Rev Phytopathol 49:291-315. https://doi.org/10.1146/annurev-phyto-080508081831

Pregitzer KS, King JA, Burton AJ, Brown SE (2000) Responses of tree fine roots to temperature. New Phytol 147:105-115

Rewald B, Rechenmacher A, Godbold DL (2014) It's complicated: intra-root system variability of respiration and morphological traits in four deciduous tree species. Plant Physiol 166:736745. https://doi.org/10.1104/pp.114.240267

Rewald B, Kunze ME, Godbold DL (2016) $\mathrm{NH}_{4}: \mathrm{NO}_{3}$ nutrition influence on biomass productivity and root respiration of poplar and willow clones. GCB Bioenergy 8:51-58. https://doi.org/10.1111/gcbb.12224

Ryle GJA, Arnott RA, Powell CE, Gordon AJ (1983) Comparisons of the respiratory effluxes of nodules and roots in six temperate legumes. Ann Bot 52:469-477. https://doi. org/10.1093/oxfordjournals.aob.a086602
Smith AM, Stitt M (2007) Coordination of carbon supply and plant growth. Plant Cell Environ 30:1126-1149. https://doi. org/10.1111/j.1365-3040.2007.01708.x

Smith KF, Culvenor RA, Humphreys MO, Simpson RJ (2002) Growth and carbon partitioning in perennial ryegrass (Lolium perenne) cultivars selected for high water-soluble carbohydrate concentrations. J Agric Sci 138:375-385. https://doi. org/10.1017/S0021859602002095

Tang M, Keck DC, Cheng W, Zeng H, Zhu B (2019) Linking rhizosphere respiration rate of three grassland species with root nitrogen concentration. Geoderma 346:84-90

Trolldenier G, von Rheinbaben W (1981) Root respiration and bacterial population of roots I. effect of nitrogen source, potassium nutrition and aeration of roots. Z Pflanzenernähr Bodenkd 144:366-377. https://doi.org/10.1002 /jpln.19811440405

Van der Werf A, Poorter H, Lambers H (1994) Respiration as dependend on a species' inherent growth rate and the nitrogen supply to the plant. In: Roy J, Garnier E (eds) A whole-plant perspective of carbon-nitrogen interactions. SPB Academic Publishing, The Hague

Westoby M, Wright IJ (2006) Land-plant ecology on the basis of functional traits. Trends Ecol Evol 21:261-268

Widén B, Majdi $\mathrm{H}$ (2001) Soil $\mathrm{CO}_{2}$ efflux and root respiration at three sites in a mixed pine and spruce forest: seasonal and diurnal variation. Can J For Res 31:786-796. https://doi. org/10.1139/cjfr-31-5-786

Yoshida S, Eguchi H (1992) Analysis of carbon translocation to root respiration in cucumber plants (Cucumis sativus L.) by ${ }^{13} \mathrm{CO}_{2}$ tracing. Biotronics 21:25-31

Publisher's note Springer Nature remains neutral with regard to jurisdictional claims in published maps and institutional affiliations. 